\title{
Mapping the Process and the Resources that are Needed to Implement A Praziquantel Mass Drug Administration Program for Children Aged Five Years Old and Below in Resource Limited Settings.
}

\section{Mhlengi Vella Ncube ( $\nabla$ mhlengivncube@yahoo.com )}

University of KwaZulu-Natal School of Nursing and Public Health https://orcid.org/0000-0002-8317-9856

Muhubiri Kabuyaya

University of KwaZulu-Natal School of Nursing and Public Health

Moses John Chimbari

University of KwaZulu-Natal School of Nursing and Public Health

\section{Research}

Keywords: Schistosomiasis, treatment, children, Praziquantel, pre-school

Posted Date: June 9th, 2020

DOl: https://doi.org/10.21203/rs.3.rs-33382/v1

License: (9) (1) This work is licensed under a Creative Commons Attribution 4.0 International License. Read Full License 


\section{Abstract}

Background The early childhood development of millions of children in some low and medium income countries may be compromised by schistosomiasis infections contracted at the age of 5 years or below. Currently there are no standard guidelines for treating schistosomiasis in children that are five years and younger using praziquantel (PZQ), the only drug that the WHO recommends to treat schistosomiasis. This review is on processes and resources involved in the treatment of schistosomiasis in children aged five years and below. Methods An electronic search for peer-reviewed articles published in the period from 2008 to 2018 (August) was done in the Academic Search Complete, CINAHL with Full Text, Health Source: Nursing/Academic Edition, and MEDLINE databases via EBSCOHost and Google Scholar databases. The search targeted journals that described the treatment of schistosomiasis in children five years and below using praziquantel. Results Twelve studies met the inclusion criteria. The process of treating schistosomiasis in the children aged five years old and below included the following activities: enrolment of the children into the treatment program; clinical examination; diagnosis; taking anthropometric measurements; feeding the children, making the PZQ palatable to the children; administration of PZQ and monitoring of side effects. There was also a variation in the resources used to treat children aged five- and below for schistosomiasis. Conclusions A PZQ mass drug administration program for children aged five years old and below in endemic areas should exclude diagnosis of schistosomiasis before treatment. The resources required in the treatment process should be affordable, should not require skills and maintenance resources that are beyond those that are available at primary healthcare level.

\section{Background}

Globally, over 240 million people mainly in impoverished communities (4), are affected by schistosomiasis [13]. One hundred and twenty three million (123 M) of people affected by schistosomiasis are children[4] and among them 23 million are below the age of 6 years. Ninety percent $(90 \%)$ of the cases of schistosomiasis are found in Sub-Saharan Africa [5, 6]. Children infected with schistosomes at the age of five years and below may have compromised development manifesting as stunted growth, lethargy, cognitive and memory impairment [7]. If children infected by schistosomes at five years and below are not treated, their academic performance may be negatively affected and hence there will be trapped in the poverty cycle in later years of their lives[7]. Thus, treatment of schistosomiasis in children five years old and below is important to prevent ailment, promote healthy development and fight poverty[8].

The World Health Organization recommends the use of Praziquantel (PZQ) to treat schistosomiasis[9]. PZQ has been used to control schistosomiasis in affected communities through mass drug administration (MDA) [3]. MDA programs have excluded children aged five years and below based on the misconception that this age group is not exposed to schistosomiasis[10] and also because they do not attend school where the programs focus[11]. Some children in communities where schistosomiasis is endemic have been diagnosed for schistosomiasis in their first year of lif e[10]. These children remain infected and unwell until the age of six when they start school and are enrolled in school-based treatment programs. Early treatment of these children will prevent morbidity, promote early childhood development and facilitate socio-economic development in affected communities[8]. 
The recommended dose of PZQ to treat schistosomiasis is $40 \mathrm{mg} / \mathrm{kg}[9]$. Merk and Bayer, when registering $P Z Q$, overlooked its purpose for the use of the drug to treat children below the age five[12]. When the need to treat this age group was realized, the use of the drug on children was done without legal protection, or evidence of safety and efficacy[12]. The WHO supported studies to determine the safety and efficacy of PZQ in children five years and below[12]. These studies showed that PZQ is safe and efficacious for treating schistosomiasis in children five years old and below $[13,14]$. Thus, WHO has recommended that children aged five years and below in endemic areas be treated at a dose of $40 \mathrm{mg} / \mathrm{kg}$ during preventive MDA programs[9]. However, there are no specific treatment guidelines for using PZQ in this age group.

Numerous challenges associated with treating schistosomiasis in children aged five years and below have been reported[12]. The PZQ tablet is bitter and difficult to swallow for young children because of its size[18]. The healthcare systems in some of the areas affected by schistosomiasis cannot afford to purchase or maintain scales[18]. In the absence of scales, WHO recommends the use of height based dose poles to determine PZQ doses[19]. The WHO approved dose pole does not cater for children who are less than $60 \mathrm{~cm}$ tall[19]. Children with stunted growth, who are in need of treatment, may fall outside the scale of the dose pole. PZQ also causes minor side effects that require close monitoring[15]. Any treatment process that is developed needs to consider these challenges.

We reviewed the processes followed in the use of PZQ to treat schistosomiasis in children aged five years and below. We reported on: the PZQ treatment process and resources that were used to treat schistosomiasis in children aged five years old and below different clinical studies; and the process followed and resources that could be used in the implementation of a PZQ MDA program targeting children under five. MDA programs for children are essential in promoting early childhood development and to contribute to ending poverty[8].

\section{Methods}

We used the scoping review methodology for this study because scoping reviews are recommended when the purpose of the study is "to examine how research is conducted on a certain topic or field."[20] The Arksey and O'Malley's framework for scoping reviews with modifications from Levacet al $[21,22]$ was used to describe the process and resources involved in treating schistosomiasis in children below 5 years old. However, we did not conduct the interviews outlined in the Arksey and O'Malley's framework (2010) methodology.

The research question for this review was: "what are the processes and resources that are required to treat schistosomiasis in children below the age of five years?"

The search terms schistosomiasis, bilharzia, treatment, Praziquantel and under five years old, pre-school children were used to find studies from the Google Scholar database. The following combination of search words and Boolean terms were used: Schistosomiasis OR bilharzia AND treatment OR praziquantel AND children under 5 years old to search for studies from the EBSCOHost database. The EBSCOHost Databases that were searched are: Academic Search Complete, CINAHL with Full Text, Health Source: Nursing/Academic Edition and MEDLINE.

The searches covered a ten-year period; January 2008 to August 2018. Only peer reviewed journal articles reporting on primary data were included in the review. Peer reviewed journal articles reporting on treatment of 
schistosomiasis in children aged five years and below using drugs other than praziquantel were excluded because $\mathrm{PZQ}$ is the only drug that has been approved by WHO for use in schistosomiasis treatment programs.

Studies, reporting on the use of Epiquantel were, however included because PZQ is the active ingredient in the Epiquantel syrup. Peer reviewed journal articles not written in English were excluded because we did not have translation resources. The searches were initially saved on libraries created in the EBSCOHost and Google Scholar databases. Completed searches were merged on to Endnote X10. EBSCOHost removed several duplicates during the transfer process. The remaining duplicates were removed using ENDNote.

The scope of the review was limited to studies reporting on the technical activities involved in the treatment of schistosomiasis of the species S. hematobium and S. mansoni in children aged five and below. We thus included all studies that reported on the use of praziquantel to treat schistosomiasis in children aged five years old and below. Studies that reported on treatment of schistosomiasis in children above five years were included if the studies also reported on treatment of under-five years old as a category. Since it is not necessary to diagnose schistosomiasis during a PZQ MDA program[23], studies reporting exclusively on the diagnosis of schistosomiasis (and did not include treatment of under children aged five years old and below in the methodology) were excluded. Title, abstract and full article screening were used to identify articles that met our inclusion criteria

A modified Donabedian framework was used to analyse the findings in our study[24]. The Donabedian framework separates operations into structure (resources), processes and outcomes[24]. We identified the processes and resources involved in the treatment of schistosomiasis in children under five years old. We then used the processes that were reported in the studies as a framework on which we constructed a treatment process that can be used to implement a schistosomiasis control MDA program for children under five years old. We also used the resources identified in the study to select those that would be appropriate for use in a schistosomiasis control MDA program for children aged five years and below.

\section{Results}

Our initial search yielded 1088 titles. After removing duplicates, titles reporting exclusively on children older than five years, review papers and studies that focused on diagnosis remained with 35 studies. Twenty-three (23) of those studies were removed after full article screening because they were focused on diagnosis or did not describe the processes, materials and outcomes that were used in the treatment process. Twelve studies met the search criteria (Fig. 1).

Twelve peer reviewed articles met our inclusion criteria (Table 1). The studies in these articles were from five different countries: Ghana (41.7\%), Ivory Coast (16.7\%), Niger (8.3\%), Sudan (8.3\%) and Zimbabwe (16.7\%). The lowest age of the children reported in the studies was 1 month old and the highest age reported was 93 months. Ten of the studies reported on the use of the praziquantel (PZQ) tablet, 1 study reported on the use of PZQ syrup and one study reported on the use of both the PZQ tablet and the PZQ syrup. 
Table 1

The 12 studies that were selected for review.

\begin{tabular}{|c|c|c|c|c|c|}
\hline $\begin{array}{l}\text { Author and } \\
\text { year of } \\
\text { publication }\end{array}$ & Country & Study title & $\begin{array}{l}\text { Study } \\
\text { aim/objective }\end{array}$ & Processes & $\begin{array}{l}\text { Structure } \\
\text { (materials) }\end{array}$ \\
\hline $\begin{array}{l}\text { Mutamad A. } \\
\text { Amin, et al, } \\
2012\end{array}$ & Sudan & $\begin{array}{l}\text { Treatment of } \\
\text { pre-school } \\
\text { children under } \\
6 \text { years of age } \\
\text { for } \\
\text { schistosomiasis: } \\
\text { safety, efficacy } \\
\text { and } \\
\text { acceptability of } \\
\text { praziquantel }\end{array}$ & $\begin{array}{l}\text { This study } \\
\text { investigated } \\
\text { safety, efficacy } \\
\text { and acceptability } \\
\text { of praziquantel } \\
\text { for the treatment } \\
\text { of } S \text {. } \\
\text { haematobium } \\
\text { and } S \text {. mansoni } \\
\text { infections among } \\
\text { pre-school } \\
\text { children aged < } \\
6 \text { years. The } \\
\text { study also } \\
\text { investigated the } \\
\text { burden of } \\
\text { schistosomiasis } \\
\text { in this age group. }\end{array}$ & $\begin{array}{l}\text { Enrolment of } \\
\text { children } \\
\text { Clinical } \\
\text { assessment } \\
\text { Diagnosis } \\
\text { Height and } \\
\text { weight } \\
\text { measurements } \\
\text { Treatment } \\
\text { Monitoring of } \\
\text { side effects }\end{array}$ & $\begin{array}{l}\text { Registers } \\
\text { Questionnaires } \\
\text { Kato-katz kit } \\
\text { Urine filtration } \\
\text { kit } \\
\text { Weight scales } \\
\text { Stadiometer } \\
\text { Praziquantel } \\
\text { Sweetener } \\
\text { (honey) } \\
\text { Food (snack) }\end{array}$ \\
\hline $\begin{array}{l}\text { Jean T. } \\
\text { Coulibaly, et } \\
\text { al ,2012 }\end{array}$ & $\begin{array}{l}\text { Co^te } \\
\text { d'Ivoire, }\end{array}$ & $\begin{array}{l}\text { Efficacy and } \\
\text { Safety of } \\
\text { Praziquantel in } \\
\text { Preschool-Aged } \\
\text { Children in an } \\
\text { Area Co- } \\
\text { Endemic for } \\
\text { Schistosoma } \\
\text { mansoni and S. } \\
\text { haematobium }\end{array}$ & $\begin{array}{l}\text { The study } \\
\text { reported here } \\
\text { was designed to } \\
\text { assess the } \\
\text { efficacy and } \\
\text { safety of crushed } \\
\text { praziquantel } \\
\text { tablets in } \\
\text { preschool-aged } \\
\text { children } \\
\text { (,6 years) in an } \\
\text { area where } \\
\text { Schistosoma } \\
\text { mansoni and } S \text {. } \\
\text { haematobium } \\
\text { coexist }\end{array}$ & $\begin{array}{l}\text { Enrolment of } \\
\text { children } \\
\text { Clinical } \\
\text { examination } \\
\text { Laboratory } \\
\text { diagnosis } \\
\text { Weight } \\
\text { measurements } \\
\text { Treatment } \\
\text { Monitoring of } \\
\text { side effects }\end{array}$ & $\begin{array}{l}\text { Registers } \\
\text { Questionnaires } \\
\text { (side effects } \\
\text { only) } \\
\text { Kato-katz kit } \\
\text { schistosomiasis } \\
\text { urine filtration } \\
\text { kit } \\
\text { POC-CCA } \\
\text { cassettes } \\
\text { Weight scales } \\
\text { PZQ } \\
\text { spoons } \\
\text { water }\end{array}$ \\
\hline
\end{tabular}




\begin{tabular}{|c|c|c|c|c|c|}
\hline $\begin{array}{l}\text { Author and } \\
\text { year of } \\
\text { publication }\end{array}$ & Country & Study title & $\begin{array}{l}\text { Study } \\
\text { aim/objective }\end{array}$ & Processes & $\begin{array}{l}\text { Structure } \\
\text { (materials) }\end{array}$ \\
\hline $\begin{array}{l}\text { Jean T. } \\
\text { Coulibaly, et } \\
\text { al,2017 }\end{array}$ & $\begin{array}{l}\text { Co^ te } \\
\text { d’Ivoire, }\end{array}$ & $\begin{array}{l}\text { Efficacy and } \\
\text { safety of } \\
\text { praziquantel in } \\
\text { preschool-aged } \\
\text { and school-aged } \\
\text { children infected } \\
\text { with } \\
\text { Schistosoma } \\
\text { mansoni: a } \\
\text { randomised } \\
\text { controlled, } \\
\text { parallel-group, } \\
\text { dose-ranging, } \\
\text { phase } 2 \text { trial }\end{array}$ & $\begin{array}{l}\text { To determine the } \\
\text { nature of the } \\
\text { dose-response } \\
\text { of praziquantel in } \\
\text { PSAC infected } \\
\text { with } S \text { mansoni } \\
\text { to determine the } \\
\text { dose of } \\
\text { praziquantel that } \\
\text { shows an } \\
\text { efficacy } \\
\text { comparable to } \\
\text { the standard } \\
\text { dose of } \\
40 \text { mg/kg in SAC } \\
\text { in an area where } \\
S \text { mansoni is } \\
\text { endemic. }\end{array}$ & $\begin{array}{l}\text { Enrolment } \\
\text { Clinical } \\
\text { examination } \\
\text { Diagnosis } \\
\text { Weight } \\
\text { measurements } \\
\text { Treatment } \\
\text { Monitoring of } \\
\text { side-effects }\end{array}$ & $\begin{array}{l}\text { Registers } \\
\text { Questionnaires } \\
\text { Kato-katz kit } \\
\text { Urine filtration } \\
\text { kit } \\
\text { POC-CCA } \\
\text { cassette } \\
\text { PZQ } \\
\text { Food (bread) } \\
\text { Sweetener } \\
\text { (syrup-flavored } \\
\text { water) } \\
\text { Pestle and } \\
\text { mortar }\end{array}$ \\
\hline $\begin{array}{l}\text { Jean T. } \\
\text { Coulibaly, et } \\
\text { al, } 2018\end{array}$ & $\begin{array}{l}\text { Côte } \\
\text { d'Ivoire }\end{array}$ & $\begin{array}{l}\text { Efficacy and } \\
\text { safety of } \\
\text { ascending doses } \\
\text { of praziquantel } \\
\text { against } \\
\text { Schistosoma } \\
\text { haematobium } \\
\text { infection in } \\
\text { preschool-aged } \\
\text { and school-aged } \\
\text { children: a } \\
\text { single-blind } \\
\text { randomised } \\
\text { controlled trial }\end{array}$ & $\begin{array}{l}\text { To assess the } \\
\text { efficacy and } \\
\text { safety of } \\
\text { escalating } \\
\text { praziquantel } \\
\text { dosages in PSAC } \\
\text { infected with } \\
\text { Schistosoma } \\
\text { haematobium }\end{array}$ & $\begin{array}{l}\text { Enrolment } \\
\text { Clinical } \\
\text { assessment } \\
\text { Diagnosis } \\
\text { Weight } \\
\text { measurements } \\
\text { Treatment } \\
\text { Monitoring of } \\
\text { side-effects }\end{array}$ & $\begin{array}{l}\text { Registers } \\
\text { Questionnaires } \\
\text { Schistosomiasis } \\
\text { urine filtration } \\
\text { kit } \\
\text { Food } \\
\text { Weight scales } \\
\text { PZQ } \\
\text { Pestle and } \\
\text { Mortar } \\
\text { Sweetener } \\
\text { (syrup flavoured } \\
\text { water) } \\
\text { Kato-Katz kit }\end{array}$ \\
\hline
\end{tabular}




\begin{tabular}{|c|c|c|c|c|c|}
\hline $\begin{array}{l}\text { Author and } \\
\text { year of } \\
\text { publication }\end{array}$ & Country & Study title & $\begin{array}{l}\text { Study } \\
\text { aim/objective }\end{array}$ & Processes & $\begin{array}{l}\text { Structure } \\
\text { (materials) }\end{array}$ \\
\hline $\begin{array}{l}\text { Amadou } \\
\text { Garba, et al, } \\
2012\end{array}$ & Niger & $\begin{array}{l}\text { Safety and } \\
\text { efficacy of } \\
\text { praziquantel } \\
\text { syrup } \\
\text { (Epiquantel®) } \\
\text { against } \\
\text { Schistosoma } \\
\text { haematobium } \\
\text { and } \\
\text { Schistosoma } \\
\text { mansoni in } \\
\text { preschool-aged } \\
\text { children in Niger }\end{array}$ & $\begin{array}{l}\text { The objective of } \\
\text { the current study } \\
\text { was to assess } \\
\text { the safety and } \\
\text { efficacy of } \\
\text { Epiquantel }{ }^{\circledR} \text { in } \\
\text { preschool-aged } \\
\text { children in Niger } \\
\text { in order to } \\
\text { provide } \\
\text { additional } \\
\text { evidence for the } \\
\text { treatment of this } \\
\text { age group with } \\
\text { praziquantel as } \\
\text { part of the } \\
\text { ongoing } \\
\text { preventive } \\
\text { chemotherapy } \\
\text { control } \\
\text { programmes } \\
\text { implemented in } \\
\text { highly endemic } \\
\text { areas }\end{array}$ & $\begin{array}{l}\text { Enrolment } \\
\text { Clinical } \\
\text { examination } \\
\text { Diagnosis } \\
\text { Weight } \\
\text { measurements } \\
\text { Treatment } \\
\text { Monitoring of } \\
\text { side-effects }\end{array}$ & $\begin{array}{l}\text { Questionnaire } \\
\text { Child health } \\
\text { booklet } \\
\text { Urine filtration } \\
\text { kit } \\
\text { Kato-katz kit } \\
\text { weight scales } \\
\text { Food (millet } \\
\text { wafer and } \\
\text { porridge) } \\
\text { PZQ syrup } \\
\text { Millimetre scale } \\
\text { pipette } \\
\text { Bottled water } \\
\text { Cup }\end{array}$ \\
\hline $\begin{array}{l}\text { Francisca } \\
\text { Mutapi, et al, } \\
2011\end{array}$ & Zimbabwe & $\begin{array}{l}\text { Schistosoma } \\
\text { haematobium } \\
\text { Treatment in 1- } \\
5 \text { Year Old } \\
\text { Children: Safety } \\
\text { and Efficacy of } \\
\text { the } \\
\text { Antihelminthic } \\
\text { Drug } \\
\text { Praziquantel }\end{array}$ & $\begin{array}{l}\text { This study } \\
\text { investigated the } \\
\text { safety and } \\
\text { efficacy of PZQ } \\
\text { treatment in such } \\
\text { children. }\end{array}$ & $\begin{array}{l}\text { Enrolment } \\
\text { Clinical } \\
\text { examination } \\
\text { Diagnosis } \\
\text { Weight } \\
\text { measurements } \\
\text { Treatment } \\
\text { Monitoring of } \\
\text { side effects }\end{array}$ & $\begin{array}{l}\text { Registers } \\
\text { Questionnaire } \\
\text { Kato-katz kit } \\
\text { Schistosomiasis } \\
\text { urine filtration } \\
\text { kit } \\
\text { Weight scales } \\
\text { PZQ } \\
\text { Sweetener } \\
\text { (juice) } \\
\text { Spoons } \\
\text { Food (bread) }\end{array}$ \\
\hline
\end{tabular}




\begin{tabular}{|c|c|c|c|c|c|}
\hline $\begin{array}{l}\text { Author and } \\
\text { year of } \\
\text { publication }\end{array}$ & Country & Study title & $\begin{array}{l}\text { Study } \\
\text { aim/objective }\end{array}$ & Processes & $\begin{array}{l}\text { Structure } \\
\text { (materials) }\end{array}$ \\
\hline $\begin{array}{l}\text { Allen } \\
\text { Nalugwa, et } \\
\text { al, } 2015\end{array}$ & Uganda & $\begin{array}{l}\text { Single Versus } \\
\text { Double Dose } \\
\text { Praziquantel } \\
\text { Comparison on } \\
\text { Efficacy and } \\
\text { Schistosoma } \\
\text { mansoni Re- } \\
\text { Infection in } \\
\text { Preschool-Age } \\
\text { Children in } \\
\text { Uganda: A } \\
\text { Randomized } \\
\text { Controlled Trial }\end{array}$ & $\begin{array}{l}\text { designed to } \\
\text { compare the } \\
\text { efficacy ofPZQ in } \\
\text { terms of CRs and } \\
\text { ERRs using } \\
\text { single and } \\
\text { double dose } \\
\text { regimens and its } \\
\text { effect on } S \text {. } \\
\text { mansoni re- } \\
\text { infection } \\
8 \text { months post } \\
\text { treatment in } \\
\text { children aged 1- } \\
5 \text { years living } \\
\text { along Lake } \\
\text { Victoria in } \\
\text { eastern Uganda. }\end{array}$ & $\begin{array}{l}\text { Enrolment } \\
\text { Diagnosis } \\
\text { Weight } \\
\text { measurement } \\
\text { Treatment } \\
\text { Monitoring of } \\
\text { side effects }\end{array}$ & $\begin{array}{l}\text { Register } \\
\text { Questionnaire } \\
\text { (side-effects) } \\
\text { Kato-katz kits } \\
\text { Weight scales } \\
\text { PZQ } \\
\text { Sweetener } \\
\text { (orange juice) } \\
\text { Water } \\
\text { Food (bread and } \\
\text { orange juice) }\end{array}$ \\
\hline $\begin{array}{l}\text { Harriet } \\
\text { Namwanje } \\
\text { et al, } 2011\end{array}$ & Uganda & $\begin{array}{l}\text { The } \\
\text { acceptability } \\
\text { and safety of } \\
\text { praziquantel } \\
\text { alone and in } \\
\text { combination } \\
\text { with } \\
\text { mebendazole in } \\
\text { the treatment of } \\
\text { Schistosoma } \\
\text { mansoni and } \\
\text { soil-transmitted } \\
\text { helminthiasis in } \\
\text { children aged 1- } \\
4 \text { years in } \\
\text { Uganda }\end{array}$ & $\begin{array}{l}\text { To determine the } \\
\text { acceptability and } \\
\text { safety of } \\
\text { praziquantel } \\
\text { alone and in } \\
\text { combination with } \\
\text { mebendazole in } \\
\text { the treatment of } \\
\text { S. mansoni and } \\
\text { STH in children } \\
\text { aged } 1 \text { to } 4 \text { years }\end{array}$ & $\begin{array}{l}\text { Enrolment } \\
\text { Clinical } \\
\text { examination } \\
\text { Diagnosis } \\
\text { Weight } \\
\text { measurements } \\
\text { Treatment } \\
\text { Monitoring of } \\
\text { side-effects }\end{array}$ & $\begin{array}{l}\text { Registers } \\
\text { Questionnaires } \\
\text { Specimen } \\
\text { containers } \\
\text { Kato-katz kits } \\
\text { Weight scales } \\
\text { PZQ } \\
\text { Mebendazole }\end{array}$ \\
\hline $\begin{array}{l}\text { A.M.D. } \\
\text { Navaratnam, } \\
\text { et al, } 2011\end{array}$ & Uganda & $\begin{array}{l}\text { Efficacy of } \\
\text { praziquantel } \\
\text { syrup versus } \\
\text { crushed } \\
\text { praziquantel } \\
\text { tablets in the } \\
\text { treatment of } \\
\text { intestinal } \\
\text { schistosomiasis } \\
\text { in Ugandan } \\
\text { preschool } \\
\text { children, with } \\
\text { observation on } \\
\text { compliance and } \\
\text { safety }\end{array}$ & $\begin{array}{l}\text { In this study, the } \\
\text { performance of } \\
\text { Epiquantel in } \\
\text { terms of } \\
\text { therapeutic } \\
\text { efficiency, non- } \\
\text { compliance and } \\
\text { side effects was } \\
\text { assessed under } \\
\text { field conditions } \\
\text { alongside the } \\
\text { crushed tablet } \\
\text { alternative. }\end{array}$ & $\begin{array}{l}\text { Enrolment } \\
\text { Clinical } \\
\text { examination } \\
\text { Diagnosis } \\
\text { Weight } \\
\text { measurements } \\
\text { Treatment } \\
\text { Monitoring of } \\
\text { side-effects }\end{array}$ & $\begin{array}{l}\text { Registers } \\
\text { Questionnaire } \\
\text { (side-effects) } \\
\text { Kato-katz kits } \\
\text { Weight scales } \\
\text { PZQ } \\
\text { PZQ syrup } \\
\text { Paracetamol } \\
\text { Sweetener } \\
\text { (juice) } \\
\text { Food (bread) }\end{array}$ \\
\hline
\end{tabular}




\begin{tabular}{|c|c|c|c|c|c|}
\hline $\begin{array}{l}\text { Author and } \\
\text { year of } \\
\text { publication }\end{array}$ & Country & Study title & $\begin{array}{l}\text { Study } \\
\text { aim/objective }\end{array}$ & Processes & $\begin{array}{l}\text { Structure } \\
\text { (materials) }\end{array}$ \\
\hline $\begin{array}{l}\text { Jose' C. } \\
\text { Sousa- } \\
\text { Figueiredo, } \\
\text { et al,2012 }\end{array}$ & Uganda & $\begin{array}{l}\text { Performance } \\
\text { and Safety of } \\
\text { Praziquantel for } \\
\text { Treatment of } \\
\text { Intestinal } \\
\text { Schistosomiasis } \\
\text { in Infants and } \\
\text { Preschool } \\
\text { Children }\end{array}$ & $\begin{array}{l}\text { This study } \\
\text { therefore aimed } \\
\text { to assess the } \\
\text { performance and } \\
\text { safety of PZQ } \\
\text { treatment in } \\
\text { under seven year } \\
\text { olds living in } \\
\text { Schistosoma } \\
\text { mansoni } \\
\text { endemic areas. }\end{array}$ & $\begin{array}{l}\text { Enrolment } \\
\text { Clinical } \\
\text { examination } \\
\text { Diagnosis } \\
\text { Weight } \\
\text { measurements } \\
\text { Treatment } \\
\text { Monitoring of } \\
\text { side effects }\end{array}$ & $\begin{array}{l}\text { Registers } \\
\text { Questionnaires } \\
\text { Kato-katz kit } \\
\text { Weight scales } \\
\text { PZQ } \\
\text { Sweetener } \\
\text { (orange juice) } \\
\text { Food (bread) } \\
\text { Spoons }\end{array}$ \\
\hline $\begin{array}{l}\text { José Carlos } \\
\text { Sousa- } \\
\text { Figueiredo, } \\
\text { et al, } 2010\end{array}$ & Uganda & $\begin{array}{l}\text { Treatment of } \\
\text { intestinal } \\
\text { schistosomiasis } \\
\text { in Ugandan } \\
\text { preschool } \\
\text { children: best } \\
\text { diagnosis, } \\
\text { treatment } \\
\text { efficacy and } \\
\text { side-effects, and } \\
\text { an extended } \\
\text { praziquantel } \\
\text { dosing pole }\end{array}$ & $\begin{array}{l}\text { To provide } \\
\text { detailed evidence } \\
\text { on occurrence of } \\
\text { intestinal } \\
\text { schistosomiasis } \\
\text { in very young } \\
\text { children ( } \leq \text { six } \\
\text { years of age), to } \\
\text { observe the } \\
\text { efficacy and } \\
\text { safety of PZQ in } \\
\text { this age-class } \\
\text { and extend the } \\
\text { current dose pole } \\
\text { to facilitate the } \\
\text { allocation of } \\
\text { treatments within } \\
\text { mass drug } \\
\text { administration } \\
\text { initiatives. }\end{array}$ & $\begin{array}{l}\text { Enrolment } \\
\text { Clinical } \\
\text { examination } \\
\text { Diagnosis } \\
\text { Weight and } \\
\text { height } \\
\text { measurements } \\
\text { Treatment } \\
\text { Monitoring of } \\
\text { side effects }\end{array}$ & $\begin{array}{l}\text { Registers } \\
\text { Questionnaires } \\
\text { Kato-katz kit } \\
\text { SEA-ELISA } \\
\text { POC-CCA } \\
\text { Weight scales } \\
\text { PZQ } \\
\text { Sweetener } \\
\text { (orange juice } \\
\text { and sugar) } \\
\text { Stadiometer * }\end{array}$ \\
\hline
\end{tabular}




\begin{tabular}{|c|c|c|c|c|c|}
\hline $\begin{array}{l}\text { Author and } \\
\text { year of } \\
\text { publication }\end{array}$ & Country & Study title & $\begin{array}{l}\text { Study } \\
\text { aim/objective }\end{array}$ & Processes & $\begin{array}{l}\text { Structure } \\
\text { (materials) }\end{array}$ \\
\hline $\begin{array}{l}\text { Welcome M. } \\
\text { Wami, et al, } \\
2016\end{array}$ & Zimbabwe & $\begin{array}{l}\text { Comparative } \\
\text { Assessment of } \\
\text { Health Benefits } \\
\text { of Praziquantel } \\
\text { Treatment of } \\
\text { Urogenital } \\
\text { Schistosomiasis } \\
\text { in Preschool and } \\
\text { Primary School- } \\
\text { Aged Children }\end{array}$ & $\begin{array}{l}\text { To determine the } \\
\text { effect of single } \\
\text { praziquantel } \\
\text { treatment on } \\
\text { Schistosoma } \\
\text { haematobium- } \\
\text { related morbidity } \\
\text { markers: } \\
\text { microhaematuria, } \\
\text { proteinuria, and } \\
\text { albuminuria. }\end{array}$ & $\begin{array}{l}\text { Enrollment } \\
\text { Clinical } \\
\text { examination } \\
\text { Diagnosis } \\
\text { Weight } \\
\text { measurements } \\
\text { Treatment } \\
\text { Monitoring of } \\
\text { side effects }\end{array}$ & $\begin{array}{l}\text { Registers } \\
\text { Questionnaires } \\
\text { Schistosomiasis } \\
\text { urine filtration } \\
\text { kit } \\
\text { Kato-katz kit } \\
\text { Urinalysis } \\
\text { dipsticks } \\
\text { CLINITEK } \\
\text { Status + } \\
\text { Analyser } \\
\text { CLINITEK } \\
\text { Microalbumin } \\
\text { Reagent Strip } \\
\text { Weight scales } \\
\text { PZQ } \\
\text { Sweetener } \\
\text { (juice) } \\
\text { Food (bread) }\end{array}$ \\
\hline
\end{tabular}

\section{Outcomes}

All the studies that we reviewed reported that praziquantel is efficacious against schistosomiasis in children under five years. The lowest PZQ dose that was efficacious against schistosomiasis in this age group was $20 \mathrm{mg} / \mathrm{kg}[25,26]$. All the studies reported on the PZQ dose of $40 \mathrm{mg} / \mathrm{kg}$ to treat schistosomiasis in this age group. The difference in PZQ efficacy observed between treatment of children aged five years old and below with a PZQ dose of $40 \mathrm{mg} / \mathrm{kg}$ and that of $60 \mathrm{mg} / \mathrm{kg}$ was insignificant[27].

All the studies we reviewed reported PZQ to be safe for use to treat schistosomiasis in children aged five years old and below. The highest safe dose of PZQ reported was $60 \mathrm{mg} / \mathrm{kg}[25,26]$. All the studies reported that there were no serious adverse events reported after treating schistosomiasis in children aged five years and below with PZQ doses of between $20 \mathrm{mg} / \mathrm{kg}$ to $60 \mathrm{mg} / \mathrm{kg}$. We recommend that the WHO recommended dose of $40 \mathrm{mg} / \mathrm{kg}$ should be used to treat schistosomiasis during schistosomiasis control MDA programs for children aged five years old and below years old.

\section{Process}

All the studies followed the same treatment sequence: enrolment of children into the program; clinical examination; diagnosis; weight and height measurements; treatment and the monitoring of side effects. Enrolment involved acquiring consent from parents and recording all the children that participated in the study. 
The enrolled children were subjected to clinical examination to make sure that the children were safe to treat. Based on the clinical examinations the children who were considered safe for treatment were those who: were generally well[13, 14, 28-31]; had had no recent illness[29] ; were not suffering from or receiving treatment for tuberculosis (TB)[29] ; did not have malaria[13]; had not undergone a major surgical procedure[29]; were not suffering from a fever[29,32] and did not have a history of adverse drug reactions[32]. The appropriate interventions were provided to the enrolled children who were illegible for PZQ treatment on the basis of ill health.

Diagnosis of schistosomiasis was done in all the studies to determine baseline prevalence and intensity in the children before treatment. Weight and height $[19,25,33]$ measurements were then done to determine the required dose of $P Z Q$ to treat children. Administration of $P Z Q$ included feeding the children to reduce side effects[34] and to increase the assimilation of PZQ[14, 28]; making the PZQ palatable for the children by breaking or crushing the tablet and mixing it with a sweeter; and feeding the tablets to the children. After orally taking in the tablet, the children were monitored for side-effects. The most immediate side effect that was observed for was vomiting the tablet within the first 20-60minutes[27, 30], in which case the tablet was readministered to the children. Other side-effects were recorded and appropriate treatment was provided to the children.

Using the processes carried out in the 12 clinical studies to treat schistosomiasis in children aged five years and below, we designed a treatment process that can be used to implement a schistosomiasis mass drug administration (MDA) program for this age group (Fig. 2). In the MDA treatment process diagnosis of schistosomiasis could be done only on a sample of the children before the clinical examination is done.

\section{Structure}

The materials that were used to treat schistosomiasis in children under five years old in the studies are listed in Table 2. In the same table we have proposed materials that could be used in a schistosomiasis MDA program for children under five years old in resource limited settings. Registers were used to enroll children into the clinical studies. For a schistosomiasis control MDA program for children under five we recommend electronic registers that are embedded in electronic tablets. The Kato-Katz and schistosomiasis urine filtration kits[25-27, 29-31, 34, 35] were the most used materials to diagnose Schistosomiasis mansoni and Schistosomiasis haematobium respectively in the studies. The stools and urine for diagnosis were collected in specimen containers[32]. Serological tests: Point-of-care circulating cathodic antigen (POC-CCA)[25, 30, 33]; soluble egg antigen enzyme-linked immunosorbent assay SEA-ELISA[33]; microalbumin reagent strips[29] and urinalysis dip sticks[29] were also used to test for schistosomiasis in the children. Questionnaires were also used for diagnosis[4, 14, 19, 25-27, 29, 31, 33]. We recommend the use of questionnaires and urine dipsticks for the diagnosis of urinary schistosomiasis and the POC-CCA for the diagnosis of intestinal schistosomiasis on the field for use in schistosomiasis control MDA programs for children aged under five years.

Questionnaires and the child health booklet[14] were used for clinical assessments. We also recommend that both be used for clinical assessments in the schistosomiasis control MDA programs for children aged under five years old and below years old. Some the studies that we reviewed reported using weight scales, while others used stadiometers [31,33] and one used dose poles[33] to obtain the anthropometric measurement that 
were used to calculate the dose amount of PZQ. We recommend the use of the dose pole and/or tape measures to make these measurements in schistosomiasis control MDA programs for young children.

Bread and juice[13, 25, 27-29, 34], millet wafer[14] and porridge[14] were the food items that were used in the studies we reviewed. PZQ tablets were crushed with spoons[27] or pestle and mortar[25, 26] to make them small enough for the children to take in. The studies used honey and sugar[31], juice and syrup flavored water as sweeteners $[13,25,27-29,34]$ to mask the bitter taste of PZQ. We recommend that children aged five years old and below should be fed with bread and juice or instant porridge during schistosomiasis control MDA programs for this age group. We recommend the use of tablets that were crushed with a pestle and mortar and juice as the sweetener for use in these MDA programs.

Some of the studies reported using schools[27, 29, 32], early childhood development (ECD) centers[29], healthcare centers[13], clinics[33] and churches[13] as sites where the children were recruited. The schools were used as treatment centers in studies that involved comparisons between children that were aged five years old and below (of pre - school aged children (PSAC)) and school aged children (SAC)[29]. The ECD centers that are reported on in the studies were attached to the schools were the SAC participants were found[29]. We recommend the use of schools and clinics as treatment centers for schistosomiasis control MDA programs for children aged five years old and below.

The human resources that took part in the clinical aspects of the studies were from a variety of healthcare professions. These medical staff included pediatricians[32], medical doctors[14], nurses[27] and laboratory technicians[25,26]. Some studies did not specify the professions of the clinical human resources only indicating that medical staff, clinicians or health officers were part of the study. One study stated the involvement of community leaders and community drug distributors[33] as part of their human resources. We recommend nurses to be the human healthcare professionals that implement the schistosomiasis control MDA programs for children aged five years old and below. 
Table 2

Materials required in the treatment of schistosomiasis in children aged five years old and below

\begin{tabular}{|c|c|c|c|}
\hline Activity & $\begin{array}{l}\text { Structure(Materials and } \\
\text { Human Resources) } \\
\text { Reported }\end{array}$ & $\begin{array}{l}\text { Structure (Materials) Recommend } \\
\text { for MDA in resource limited } \\
\text { settings. }\end{array}$ & $\begin{array}{l}\text { Reasons for } \\
\text { Selection }\end{array}$ \\
\hline \multirow[t]{2}{*}{ Enrolment } & \multirow[t]{2}{*}{ Registers } & \multirow[t]{2}{*}{ Tablets } & Eco-friendly. \\
\hline & & & Easy to use \\
\hline \multirow[t]{10}{*}{ Diagnosis } & & \multirow{10}{*}{$\begin{array}{l}\text { Urine dipsticks } \\
\text { POC-CCA }\end{array}$} & Easy to use \\
\hline & $\begin{array}{l}\text { CLINITEK Status + } \\
\text { Analyser }\end{array}$ & & \multirow[t]{9}{*}{ Easy to use } \\
\hline & $\begin{array}{l}\text { CIINITEK } \\
\text { Microalbumin } \\
\text { Reagent Strip }\end{array}$ & & \\
\hline & Kato-Katz kit & & \\
\hline & POC-CCA kit & & \\
\hline & Questionnaires & & \\
\hline & SEA-ELISA & & \\
\hline & $\begin{array}{l}\text { Schistosomiasis } \\
\text { urine filtration kit }\end{array}$ & & \\
\hline & Specimen containers & & \\
\hline & Urinalysis dip sticks & & \\
\hline \multirow{3}{*}{$\begin{array}{l}\text { Clinical } \\
\text { Examination }\end{array}$} & & \multirow{3}{*}{$\begin{array}{l}\text { Child health booklet } \\
\text { Questionnaire }\end{array}$} & \multirow{3}{*}{$\begin{array}{l}\text { Easy to access } \\
\text { Easy to use }\end{array}$} \\
\hline & Questionnaires & & \\
\hline & Child health booklet & & \\
\hline \multirow{3}{*}{$\begin{array}{l}\text { Weight/Height } \\
\text { measurements }\end{array}$} & Dose pole & Dose pole & Low cost \\
\hline & Stadiometers & \multirow[t]{2}{*}{ Tape measures } & \multirow[t]{2}{*}{ Easy to maintain } \\
\hline & Weight scale & & \\
\hline \multirow{7}{*}{$\begin{array}{l}\text { Food and } \\
\text { sweetener }\end{array}$} & & \multirow{7}{*}{$\begin{array}{l}\text { Bread } \\
\text { Juice }\end{array}$} & \multirow{7}{*}{$\begin{array}{l}\text { Easy to access } \\
\text { Easy to access }\end{array}$} \\
\hline & Bread & & \\
\hline & Honey & & \\
\hline & Juice & & \\
\hline & Millet wafer & & \\
\hline & Porridge & & \\
\hline & $\begin{array}{l}\text { syrup flavoured water } \\
\text { sugar }\end{array}$ & & \\
\hline
\end{tabular}




\begin{tabular}{|c|c|c|c|}
\hline Activity & $\begin{array}{l}\text { Structure(Materials and } \\
\text { Human Resources) } \\
\text { Reported }\end{array}$ & $\begin{array}{l}\text { Structure (Materials) Recommend } \\
\text { for MDA in resource limited } \\
\text { settings. }\end{array}$ & $\begin{array}{l}\text { Reasons for } \\
\text { Selection }\end{array}$ \\
\hline \multirow{8}{*}{$\begin{array}{l}\text { Administration } \\
\text { of PZQ }\end{array}$} & & Pestle and Mortar & Low cost \\
\hline & Cups & Spoons & \multirow{7}{*}{$\begin{array}{l}\text { Low cost and easy } \\
\text { to use }\end{array}$} \\
\hline & Millimetre pipette & \multirow[t]{6}{*}{ PZQ tablets } & \\
\hline & Pestle and mortar & & \\
\hline & PZQ syrup & & \\
\hline & PZQ tablets & & \\
\hline & Spoons & & \\
\hline & Water & & \\
\hline \multirow[t]{4}{*}{ Infrastructure } & & \multirow{4}{*}{$\begin{array}{l}\text { Clinics } \\
\text { Crèches/ECD centres } \\
\text { Faith-based establishments. }\end{array}$} & \multirow{4}{*}{$\begin{array}{l}\text { Easy to access } \\
\text { Easy to access } \\
\text { Already used for } \\
\text { some healthcare } \\
\text { programs }\end{array}$} \\
\hline & $\begin{array}{l}\text { Clinics } \\
\text { ECD centres }\end{array}$ & & \\
\hline & $\begin{array}{l}\text { Faith-based } \\
\text { establishments. } \\
\text { Healthcare centres }\end{array}$ & & \\
\hline & Schools & & \\
\hline \multirow{5}{*}{$\begin{array}{l}\text { Human } \\
\text { Resources. }\end{array}$} & $\begin{array}{l}\text { Community Health } \\
\text { Workers }\end{array}$ & \multirow{5}{*}{$\begin{array}{l}\text { Community Health Workers. } \\
\text { Nurses }\end{array}$} & Available in situ \\
\hline & Laboratory technicians & & \multirow[t]{4}{*}{ Available in situ. } \\
\hline & Medical Doctors & & \\
\hline & Nurses & & \\
\hline & Paediatricians & & \\
\hline
\end{tabular}

\section{Challenges}

Some of the studies reported the use of the current WHO approved 600mg PZQ dose tablet formulation as a challenge when treating schistosomiasis in children aged five years old and below, especially when implementing a large scale treatment program $[25,34,36]$. They recommended that a variation of this formulation with three partitions that make it possible to split the tablet into four pieces of $150 \mathrm{mg}$ each should be used when treating schistosomiasis in children aged five years old and below so as to ensure the use of the correct PZQ to treat schistosomiasis in these children[33]. The studies proposed that a pediatric formulation should be developed and that the PZQ pediatric formulations could be an orally dispensable tablet[25] or a PZQ syrup[14].

\section{Discussion}


The objective of this study was to map the processes, and resources that are required to implement a schistosomiasis control MDA program for children aged five years old and below. A schistosomiasis control MDA program for children aged five years old and below years old has not been reported on. The closest to a schistosomiasis MDA program for this age group is mainly clinical studies that were recommended by WHO to determine the safety and efficacy of treating schistosomiasis in children aged five years old and below using praziquantel[12]. We modified the processes that were used in these studies to propose a treatment process to execute a schistosomiasis control MDA program for children aged five years and below.

\section{Process}

The praziquantel treatment process used in an MDA program for children aged five years old and below could follow the sequence: enrolment of children; clinical examination; weight and height measurements; treatment and the monitoring of side effects for all the children. This is in line with recommendations of the WHO that individual diagnosis of schistosomiasis prior to treatment is not required before treatment during an MDA program[23]. The studies we reviewed diagnosed all the children in order to determine the prevalence of schistosomiasis in the children that are aged five years and below and also to determine the efficacy of PZQ in treating schistosomiasis in these children. The diagnosis of schistosomiasis in the MDA program is important to determine the baseline prevalence and burden of infectivity of schistosomiasis in the children for the purposes of monitoring and evaluation[37]. Diagnosis of schistosomiasis in a schistosomiasis control MDA program for children aged five years old and below for monitoring and evaluation could be done on a random sample of the children soon after they have been enrolled into the treatment program[38]. In some cases, the baseline prevalence and infection intensity could be done separately from the MDA program during disease surveillance programs making the treatment process to move directly from enrolment of the children to clinical assessments[39]. The disease surveillance programs when present could be used to monitor and evaluate the schistosomiasis control MDA program for children aged five years and below.

\section{Structure}

The Donabedian framework refers to resources as structural components of a healthcare system[24]. The resources that are required to implement a schistosomiasis control MDA program for children aged five years old and below should be applicable to the environment in which the MDA program will be implemented[40]. Most of the places where schistosomiasis is endemic are economically disadvantaged and therefor suffer from resource constraints. We used relative cost and ease of access to select the resources that we recommended to be the best for use in a schistosomiasis control MDA program for children aged five years and below. The resources used should also be eco-friendly[41].

None of the studies described the nature of the registers that they used for enrolment. Electronic registers that are embedded in tablets could be used to enrol children into a schistosomiasis control MDA program. The use of electronic information management systems in the MDA program could be extended to storing and analysing: the clinical assessments of the children to identify other childhood illnesses that need mass intervention. Tablets can be used for controlling the quality of the medical information about the children that is requested using questionnaires; for managing and monitoring the program's consumables inventory and for monitoring and evaluation of the progress and impact of the MDA program. A multinational study conducted 
in low and medium income countries (Ghana, Kenya, India and Pakistan) reported that the initial cost of purchasing electronic tablets and software licensing costs for healthcare program data management could be high[42]. However, because the tablets could be used multiple times in the same program and also across different programs, the purchase of tablets could be a justifiable investment when taking into account economies of scale and economies of scope in healthcare program implementation cost analysis[42, 43]. The limitations of using electronic tablets could include intermittent electricity supply and internet coverage in some of the areas where the schistosomiasis control MDA program could be necessary[42, 44]. The use of paper based registers is most common and carries some hidden costs[42]. When the initial cost of buying and setting up electronic systems for treatment data management cannot be afforded, paper based registers could be used.

The WHO recommends that diagnosis should not be made a requirement for the mass drug administration of praziquantel in schistosomiasis endemic areas[23]. Diagnosis could however be used for the purposes of monitoring and evaluation of a schistosomiasis control MDA program. To diagnose schistosomiasis in children aged five years old and below for the purposes of monitoring and evaluating a schistosomiasis control MDA program targeting this age group, urine deep stick to detect haematuria caused by urinary schistosomiasis and the POC-CCA to detect intestinal schistosomiasis could be used. Both these methods have the advantages of being performed at the site of the MDA program and are more sensitive that the microscopy based methods that are normally used to diagnose schistosomiasis in school going children[40, $45,46]$. The urinary dipstick and POC-CCA point of care tests do not require specialised human resources, in particular laboratory technicians, to carry out the testing. Other methods such as the PCR and the FLOTAC technologies require additional specially skilled technicians and equipment such as thermocyclers and centrifuges which cannot be used on the field[47].

The activities that are involved in treating schistosomiasis in children aged five years and below include taking weight or height measurements; calculating dosage; feeding the children; making PZQ more palatable to the children and administering the PZQ to the children. Height rather than weight could be used to determine the dose of PZQ to be given to the children[19]. This is because the dose poles that are used to measure height are less expensive to buy and to maintain compared to the weight scales that could be used in the event that weight is used to determine dosage[48]. The extended dose pole by Sousa-Figueiredo et al,2012 addresses the limitation of the exclusion of children shorter than $94 \mathrm{~cm}$ from being treated based on the dose pole[19]. The use of electronic health systems management could eliminate the need for dose poles and weight scales by providing data that could be used to perform weight-for-age calculations[49]. The age of the child could then be used to calculate the appropriate PZQ dose to treat the children[49].

We recommend that bread and juice are the most suitable foods to feed the children before treatment. This is because bread and juice are filling and yet easily available in most communities and also require very little labour to prepare[50]. Fortified spreads could be used on the bread to enhance the nutritional value of the bread[51]. Juice also has the added capability to sweeten the PZQ making it more palatable for the children[52]. An alternative to bread and juice could be fortified cereal[53]. Fortified has the advantage of providing multi-nutrients to children[53] thereby addressing the needs of the schistosomiasis control MDA program for children aged five years old and below and also tackling the challenge of malnutrition[54]. Schistosomiasis and childhood often exist as co-epidemics[18,54]. The studies reported using either pestle 
and mortar or spoons to crush the PZQ tablets. Ideally the pestle and mortar could be used. This is because the pestle and mortar are the best tools to use to crush the tablets and are also inexpensive[55]. Spoons are less efficient at crushing tablets but could also be used when pestle and mortar are not available.

Schistosomiasis control MDA programs for children aged five years old and below could be carried out in clinics or schools. The use of clinics for such an MDA program is encouraged by the WHO[9]. Schools on the other hand have been successfully used by schistosomiasis control MDA programs to treat SAC[27, 56]. Since some ECD centres are attached to schools, the same operational strategies that have been used to target SAC can be used to target PSAC[27, 29]. Children who are not enrolled in ECD centres can be invited to be part of the MDA program. Faith-based establishments such as churches and mosques are used for healthcare programs in some resource limited settings $[57,58]$ and could be used to mobilize people to enrol their under five children in the schistosomiasis control MDA program [59,60]. Faith-based establishments could also be used as treatment sites for the MDA program. The choice between using clinics, ECD centres, crèches and faith-based establishments depends on the prevailing government policy and on where the children under five years who are at risk of schistosomiasis could be best accessed for treatment in the community where the MDA program is required.

The studies we reviewed reported on using a variety of human resources such as paediatricians, medical doctors, nurses, laboratory technicians and community health works. Paediatricians, medical doctors and laboratory technicians are seldom available in resource limited settings such as those that are affected by schistosomiasis[61]. Nurses could therefore implement the schistosomiasis control MDA program for children aged five years old and below. This is because nurses have been found to successfully implement paediatric healthcare interventions at primary healthcare level in the resource limited setting that schistosomiasis is mostly found[62]. Due to human resources constrains in most areas affected by schistosomiasis community health workers are needed to support the clinicians in $\operatorname{MDA}$ programs $[63,64]$. Considerations of the disruption of routine curative functions of the nurses in the clinics where the nurses normally work and the remuneration motivation of community care givers should be taken into account when developing a human resources strategy for the implementation of an MDA program $[61,65]$ to control schistosomiasis in children aged five years old and below.

The strengths of this study are that the studies are from five different countries which makes them generalizable to resource limited settings in Africa and similar settings globally. The limitations of the study are that we did not perform interviews as recommended by Arksey and O'Malley's framework for systematic reviews[21]. The interviews would have given us more information on the resources that are applicable for use in schistosomiasis control MDA programs for children under five years in different settings. We, however could not perform these interviews due to challenges in getting authorization from several countries to conduct the interviews within the duration of the study.

\section{Conclusion}

The process that could be followed in the implementation of a schistosomiasis control MDA program for children aged five years old and below is: enrolment of children into the treatment program; clinical examination; weight and height measurements; treatment and the monitoring of side effects for all the

Page 17/25 
children (Fig. 2). Diagnosis could be done for the purpose of monitoring and evaluation either before the MDA program or immediately after the enrolment stage of the MDA program. The resources that could be used for the treatment program are: electronic tablets; urine dipsticks; POC-CCA; child health booklet; questionnaire; dose pole; tape measures; bread, juice, pestle and mortar; spoons; PZQ tablets; clinics and ECD centres. The availability of these resources in different healthcare centres may vary resulting in the need for unavailable resources to be purchased prior to the program. Resources that are already available and routinely in use at primary healthcare care level should be prioritized for use in the MDA program.

\section{Abbreviations}

\begin{tabular}{|ll|}
\hline ALB: & Albendazole \\
\hline ECD: & Early Childhood Development \\
\hline HAART: & highly active antiretroviral therapy \\
\hline MEDLINE: & Medical Literature Analysis and Retrieval System Online \\
\hline POC CCA & Point-of-care Circulating Cathodic Antigen \\
\hline PSAC & Pre-School Aged Children \\
\hline PZQ: & Praziquantel \\
\hline SAC & School Aged Children \\
\hline SEA-ELISA & Soluble Egg Antigen Enzyme-Linked Immunosorbent Assay \\
\hline STH: & Soil Transmitted Helminths \\
\hline TB: & Tuberculosis \\
\hline UKZN: & University of KwaZulu-Natal \\
\hline WHO: & World Health Organisation \\
\hline
\end{tabular}

\section{Declarations}

\section{Acknowledgements}

The authors are grateful for the support provided by Dr Elizabeth Ojewole and Dr Resign Gunda in reviewing the manuscript. The authors would like to acknowledge the College of Health Sciences (CHS) through CHS scholarship program at the University of KwaZulu-Natal for their financial support. This research was commissioned by the National Institute of Health Research using Official Development Assistance (ODA) funding. The views expressed in this publication are those of the author(s) and not necessarily those of the NHS, the National Institute of Health Research, or the Department of Health.

\section{Availability of data and materials}

Data will be made available upon request 


\section{Ethics approval and consent to participate}

Not applicable.

\section{Funding}

University of KwaZulu-Natal

NIHR Global Health Research Unit Tackling Infections To Benefit Africa

British Academy's Early Childhood Development Program

\section{Authors' contributions}

MVN conceived the in collaboration with CM and MC. MVN designed the search strategy. MV performed searches. MVN and KM conducted data selection and extraction. All authors were involved in data analysis and interpretation of results. All authors revised and approved the final manuscript.

\section{Consent for publication}

All authors consent and approve the manuscript for publication.

\section{Competing interests}

The authors declare no that they have no competing interests.

\section{Ethics approval and consent to participate}

Not applicable.

\section{Author details}

${ }^{1}$ School of Nursing and Public Health, College of Health Sciences, University of KwaZulu- Natal, Durban, South Africa

\section{References}

1. Mo AX, et al. Schistosomiasis elimination strategies and potential role of a vaccine in achieving global health goals. Am J Trop Med Hyg. 2014;90(1):54-60.

2. Ross AG, et al. Can mass drug administration lead to the sustainable control of schistosomiasis? The Journal of infectious diseases. 2014;211(2):283-9.

3. Olveda DU, McManus DP, Ross AG. Mass drug administration and the global control of schistosomiasis: successes, limitations and clinical outcomes. Curr Opin Infect Dis. 2016;29(6):595-608.

4. Mduluza T, Mutapi F. Putting the treatment of paediatric schistosomiasis into context. Infectious Diseases of Poverty. 2017;6:85. 
5. French MD, et al. Schistosomiasis in Africa: Improving strategies for long-term and sustainable morbidity control. PLOS Neglected Tropical Diseases. 2018;12(6):e0006484.

6. WHO. Schistosomiasis and soil-transmitted helminthiases: number of people treated in 2016. Wkly Epidemiol Rec. 749-760, 2017(49): p. 749-760.

7. Adenowo AF, et al. Impact of human schistosomiasis in sub-Saharan Africa. Brazilian Journal of Infectious Diseases. 2015;19:196-205.

8. Dabo A, et al. Factors associated with coverage of praziquantel for schistosomiasis control in the community-direct intervention (CDI) approach in Mali (West Africa). Infectious Diseases of Poverty. 2013;2(1):11.

9. WHO. Schistosomiaisis Control and preventive chemotherapy. 2018 [cited 2018; Available from: http://www.who.int/schistosomiasis/strategy/en/.

10. Stothard JR, et al. Closing the praziquantel treatment gap: new steps in epidemiological monitoring and control of schistosomiasis in African infants and preschool-aged children. Parasitology. 2011;138(12):1593-606.

11. Osakunor DNM, et al., Dynamics of paediatric urogenital schistosome infection, morbidity and treatment: a longitudinal study among preschool children in Zimbabwe. BMJ Global Health, 2018. 3(2).

12. Stothard JR, et al. Schistosomiasis in African infants and preschool children: let them now be treated! Trends in Parasitology. 2013;29(4):197-205.

13. Navaratnam AMD, et al. Efficacy of praziquantel syrup versus crushed praziquantel tablets in the treatment of intestinal schistosomiasis in Ugandan preschool children, with observation on compliance and safety. Transactions Of The Royal Society Of Tropical Medicine Hygiene. 2012;106(7):400-7.

14. Garba A, et al. Safety and efficacy of praziquantel syrup (Epiquantel ${ }^{\circledR}$ ) against Schistosoma haematobium and Schistosoma mansoni in preschool-aged children in Niger. Acta Trop. 2013;128(2):318-25.

15. Bayer. Batricide (Praziquantel) Fact scheet. 2010; Available from: https://www.accessdata.fda.gov/drugsatfda_docs/label/2010/018714s012lbl.pdf.

16. Sikalengo G, et al. Distinct clinical characteristics and helminth co-infections in adult tuberculosis patients from urban compared to rural Tanzania. Infectious Diseases of Poverty. 2018;7(1):24.

17. Mazigo HD, et al. Praziquantel efficacy against Schistosoma mansoni among HIV-1 infected and uninfected adults living in fishing villages along Lake Victoria, Northwest Tanzania. Infectious Diseases of Poverty. 2014;3(1):47.

18. Osakunor DNM, Woolhouse MEJ, Mutapi F. Paediatric schistosomiasis: What we know and what we need to know. PLOS Neglected Tropical Diseases. 2018;12(2):e0006144.

19. Sousa-Figueiredo JC, Betson M, Stothard JR. Treatment of schistosomiasis in African infants and preschool-aged children: downward extension and biometric optimization of the current praziquantel dose pole. International Health. 2012;4(2):95-102.

20. Munn Z, et al. Systematic review or scoping review? Guidance for authors when choosing between a systematic or scoping review approach. BMC medical research methodology. 2018;18(1):143-3. 
21. Arksey H, O'Malley L. Scoping studies: towards a methodological framework. Int J Soc Res Methodol. 2005;8(1):19-32.

22. Levac D, Colquhoun H, O'Brien KK. Scoping studies: advancing the methodology. Implementation Science: IS. 2010;5:69-9.

23. WHO. Preventive chemotherapy in human helminthiasis, in Manual on preventive chemotherapy. 2006.

24. Donabedian A. Evaluating the quality of medical care. The Milbank Quarterly. 2005;83(4):691-729.

25. Coulibaly JT, et al. Efficacy and safety of praziquantel in preschool-aged and school-aged children infected with Schistosoma mansoni: a randomised controlled, parallel-group, dose-ranging, phase 2 trial. The Lancet Global Health. 2017;5(7):e688-98.

26. Coulibaly JT, et al. Efficacy and safety of ascending doses of praziquantel against Schistosoma haematobium infection in preschool-aged and school-aged children: a single-blind randomised controlled trial. BMC Med. 2018;16(1):81.

27. Mutapi F, et al. Schistosoma haematobium treatment in 1-5 year old children: safety and efficacy of the antihelminthic drug praziquantel. PLoS Negl Trop Dis. 2011;5(5):e1143.

28. Sousa-Figueiredo J, et al. Performance and Safety of Praziquantel for Treatment of Intestinal Schistosomiasis in Infants and Preschool Children. PLOS Neglected Tropical Diseases. 2012;6(10):e1864.

29. Wami WM, et al., Comparative Assessment of Health Benefits of Praziquantel Treatment of Urogenital Schistosomiasis in Preschool and Primary School-Aged Children. Biomed Research International, 2016. 2016: p. 9162631-9162631.

30. Coulibaly JT, et al., Efficacy and safety of praziquantel in preschool-aged children in an area co-endemic for Schistosoma mansoni and S. haematobium. PLoS neglected tropical diseases, 2012. 6(12): p. e1917.

31. Amin M, et al. Treatment of pre-school children under 6 years of age for schistosomiasis: safety, efficacy and acceptability of praziquantel. Sudan Journal of Medical Sciences. 2012;7(2):67-76.

32. Namwanje $H$, Kabatereine NB, Olsen A. The acceptability and safety of praziquantel alone and in combination with mebendazole in the treatment of Schistosoma mansoni and soil-transmitted helminthiasis in children aged 1-4 years in Uganda. Parasitology. 2011;138(12):1586-92.

33. Sousa-Figueiredo JC, et al. Treatment of intestinal schistosomiasis in Ugandan preschool children: best diagnosis, treatment efficacy and side-effects, and an extended praziquantel dosing pole. International Health. 2010;2(2):103-13.

34. Nalugwa A, et al. Single Versus Double Dose Praziquantel Comparison on Efficacy and Schistosoma mansoni Re-Infection in Preschool-Age Children in Uganda: A Randomized Controlled Trial. Plos Neglected Tropical Diseases. 2015;9(5):e0003796-6.

35. Garba A, et al. Schistosomiasis in infants and preschool-aged children: Infection in a single Schistosoma haematobium and a mixed S. haematobium-S. mansoni foci of Niger. Acta Trop. 2010;115(3):212-9.

36. Davis PS, Schul PL. Addressing the contingent effects of business unit strategic orientation on relationships between organizational context and business unit performance. J Bus Res. 1993;27(3):183200.

37. Olveda RM, et al. Efficacy and safety of praziquantel for the treatment of human schistosomiasis during pregnancy: a phase 2, randomised, double-blind, placebo-controlled trial. Lancet Infect Dis. 
2016;16(2):199-208.

38. Martin DL, et al. Serology for trachoma surveillance after cessation of mass drug administration. PLoS Negl Trop Dis. 2015;9(2):e0003555.

39. Health Do, South Africa National Master Plan for the Elimination of Neglected Tropical Diseases (20192025). 2019, South African Department of Health.

40. Betson M, et al. Intestinal schistosomiasis in mothers and young children in Uganda: investigation of field-applicable markers of bowel morbidity. Am J Trop Med Hyg. 2010;83(5):1048-55.

41. Avinash B, et al. Going green with eco-friendly dentistry. J Contemp Dent Pract. 2013;14(4):766.

42. Dickinson FM, et al. Using electronic tablets for data collection for healthcare service and maternal health assessments in low resource settings: lessons learnt. BMC Health Services Research. 2019;19(1):336.

43. Turner $\mathrm{HC}$, et al. Economic evaluations of mass drug administration: The importance of economies of scale and scope. Clin Infect Dis. 2017;66(8):1298-303.

44. King $C$, et al. Electronic data capture in a rural African setting: evaluating experiences with different systems in Malawi. Global health action. 2014;7(1):25878.

45. Ochodo EA, et al., Rapid screening and diagnostic tests for human schistosomiasis in endemic areas. Cochrane Database of Systematic Reviews, 2012(2).

46. Sousa-Figueiredo JC, et al., The urine circulating cathodic antigen (CCA) dipstick: a valid substitute for microscopy for mapping and point-of-care diagnosis of intestinal schistosomiasis. PLoS neglected tropical diseases, 2013. 7(1): p. e2008.

47. Utzinger J, et al. New diagnostic tools in schistosomiasis. Clin Microbiol Infect. 2015;21(6):529-42.

48. Mutapi F. Changing policy and practice in the control of pediatric schistosomiasis. Pediatrics. 2015;135(3):536-44.

49. Olliaro PL, et al. Practical dosing of praziquantel for schistosomiasis in preschool-aged children. Tropical Med Int Health. 2013;18(9):1085-9.

50. Leyvraz M, et al. Food consumption, knowledge, attitudes, and practices related to salt in urban areas in five sub-saharan African countries. nutrients. 2018;10(8):1028.

51. Matilsky DK, et al. Supplementary Feeding with Fortified Spreads Results in Higher Recovery Rates Than with a Corn/Soy Blend in Moderately Wasted Children. The Journal of Nutrition. 2009;139(4):773-8.

52. Bunupuradah T, et al. Use of taste-masking product, FLAVORx, to assist Thai children to ingest generic antiretrovirals. AIDS Research Therapy. 2006;3(1):30.

53. Bulusu S, et al., Cereal fortification programs in developing countries, in Issues in Complementary Feeding. 2007, Karger Publishers. p. 91-105.

54. Frigerio $S$, et al. Schistosoma haematobium infection, health and nutritional status in school-age children in a rural setting in Northern Senegal. Minerva pediatrica. 2016;68(4):282-7.

55. Thong MY, Manrique YJ, Steadman KJ. Drug loss while crushing tablets: Comparison of 24 tablet crushing devices. PLOS ONE. 2018;13(3):e0193683.

56. Burnim M, Ivy JA, King CH. Systematic review of community-based, school-based, and combined delivery modes for reaching school-aged children in mass drug administration programs for schistosomiasis. PLoS Negl Trop Dis. 2017;11(10):e0006043. 
57. Blevins J, et al. The percentage of HIV treatment and prevention services in Kenya provided by faith-based health providers. Development in Practice. 2017;27(5):646-57.

58. Berra K, Franklin B, Jennings C. Community-Based Healthy Living Interventions. Prog Cardiovasc Dis. 2017;59(5):430-9.

59. Peterson J, Atwood JR, Yates B. Key elements for church-based health promotion programs: outcomebased literature review. Public Health Nurs. 2002;19(6):401-11.

60. King R, et al. Involving mosques in health promotion programmes: a qualitative exploration of the MCLASS intervention on smoking in the home. Health Educ Res. 2017;32(4):293-305.

61. Coulibaly Y, et al., Programme activities: a major burden for district health systems? Tropical Medicine \& International Health, 2008. 13(12): p. 1430-1432.

62. Janssen N, et al. Successful paediatric HIV treatment in rural primary care in Africa. Arch Dis Child. 2010;95(6):414-21.

63. Nandha B, et al. Delivery strategy of mass annual single dose DEC administration to eliminate lymphatic filariasis in the urban areas of Pondicherry, South India: 5 years of experience. Filaria Journal. 2007;6(1):7.

64. Dean L, et al. Tailoring mass drug administration to context: implementation research is critical in achieving equitable progress in the control and elimination of helminth neglected tropical diseases in subSaharan Africa. International health. 2016;8(4):233-4.

65. Hodges $\mathrm{MH}$, et al., Maintaining effective mass drug administration for lymphatic filariasis through inprocess monitoring in Sierra Leone. Parasites \& Vectors, 2012. 5(1): p. 232.

\section{Figures}




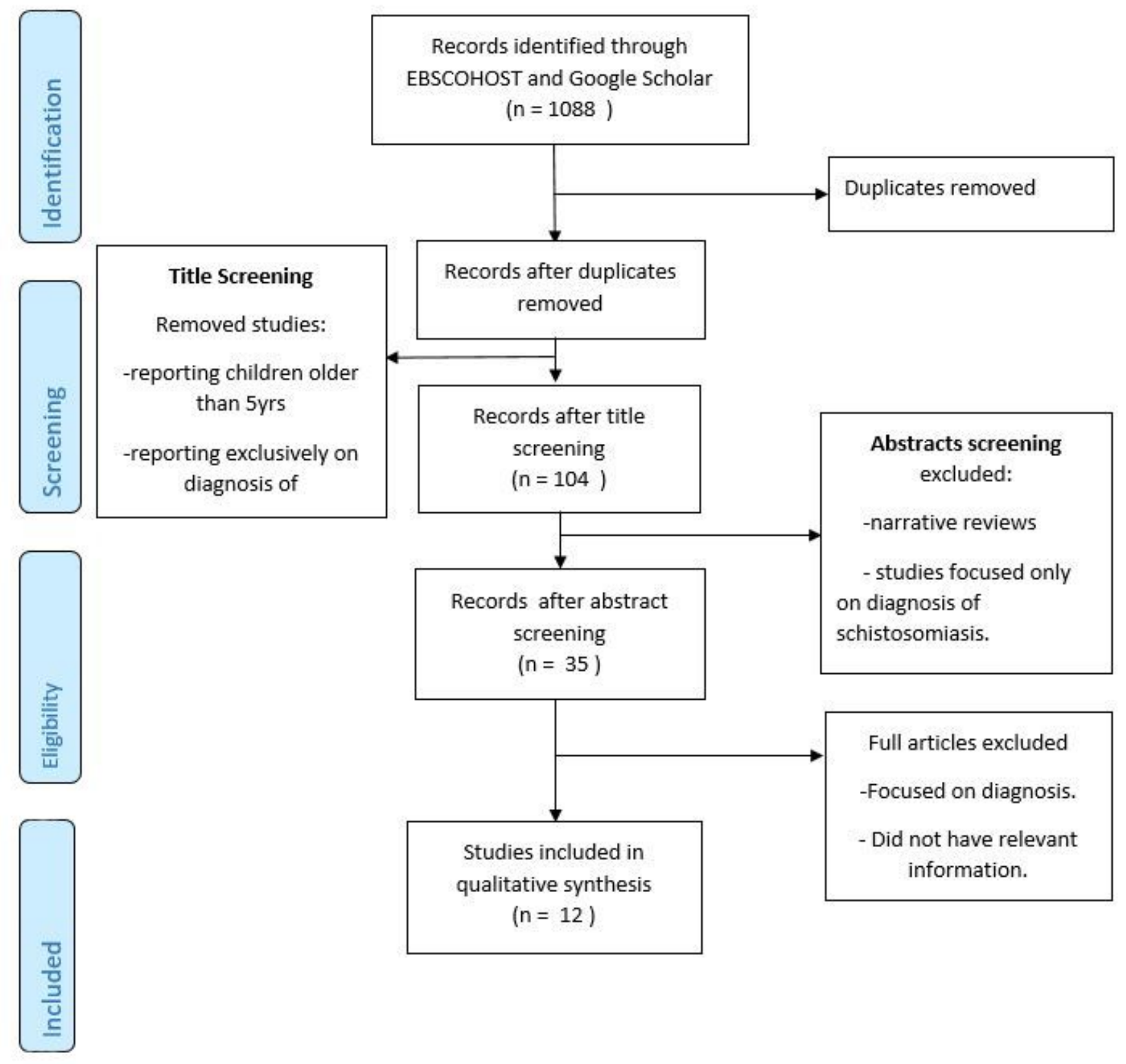

Figure 1

PRISMA chart describing the search process for selecting final papers for the review 


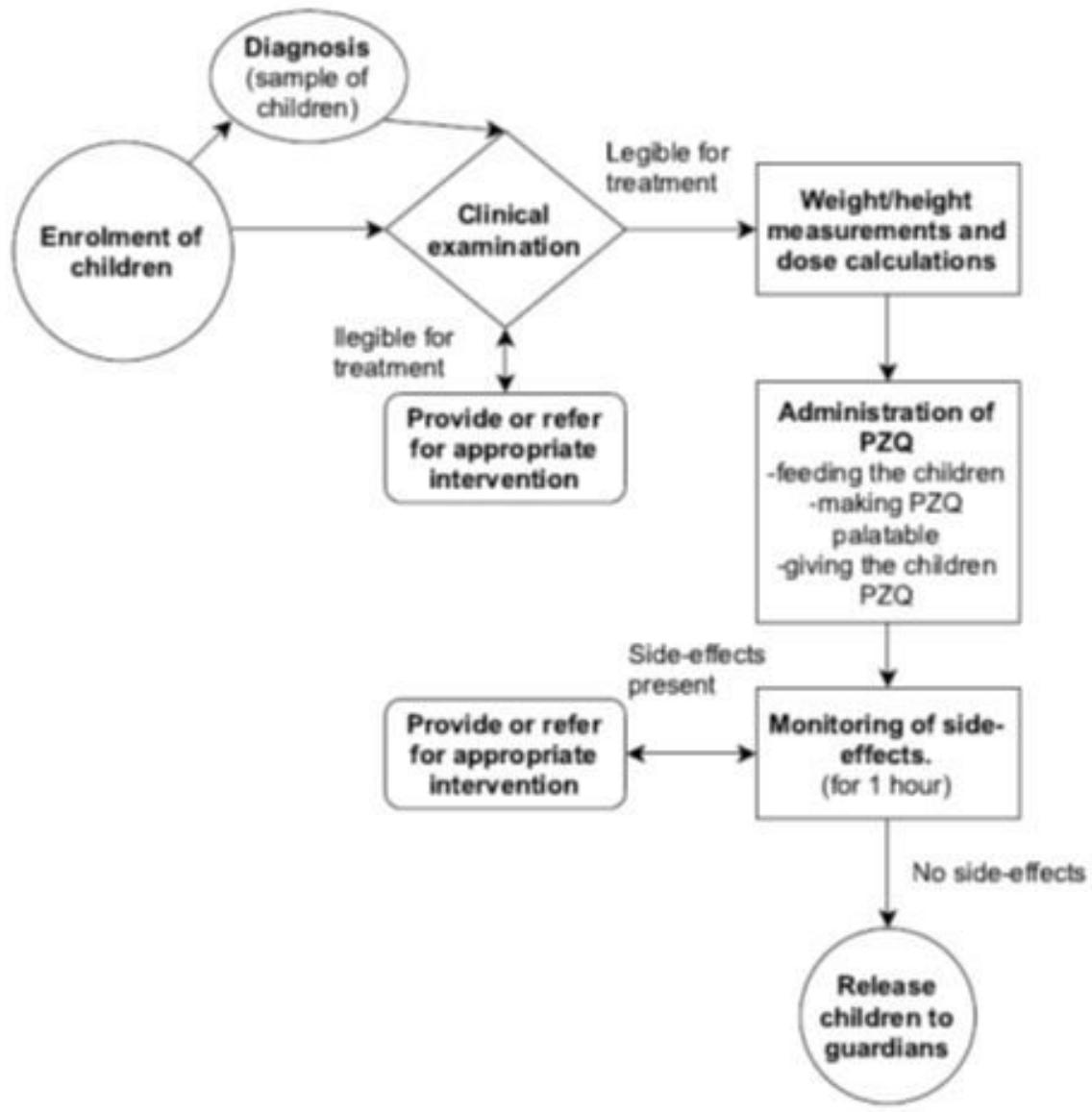

\section{Figure 2}

Treatment process flow diagram for a schistosomiasis control MDA program for children aged five years old and below.

\section{Supplementary Files}

This is a list of supplementary files associated with this preprint. Click to download.

- supplement4.docx 